\title{
SÍNDROME DE BODY-PACKER*
}

\author{
Drs. Antonio Palomeque J. ${ }^{1}$, Salvador Francisco Calzado B. ${ }^{1}$, \\ Montserrat Reyes M. ${ }^{1}$, Paul Sebastián Robayo S. ${ }^{1}$
}

1 Hospital Santa Ana. U.G.C. Cirugía y sus especialidades.

Motril, Granada, España.

\section{Body-Packer syndrome}

Varón de 52 años, con antecedentes de sigmoidectomía, trastorno límite de la personalidad e hipertenso, que consulta por distensión abdominal, vómitos y diarrea. La radiología simple (Figura 1) y tomografía computarizada abdominal muestran múltiples cuerpos extraños, produciendo cuadro de obstrucción abdominal, compatibles con un caso de Síndrome de Body-Packer. Tras actitud conservadora durante $24 \mathrm{~h}$, sin mejoría clínica, se interviene quirúrgicamente, realizándose enterotomía (Figura 2) y extracción de 42 paquetes de resina de hachis (Figura 3), con evolución satisfactoria.

El término de "body-packer" (BP) ("mula", "correo" o "culero") hace referencia a sujetos portadores de objetos extraños intraabdominales, con diferentes envoltorios, que contienen cocaína, más frecuentemente, hachís, anfetaminas u otras drogas, con fines de contrabando. La cantidad de cápsulas transportadas es mayor si la vía de introducción es la oral ${ }^{1}$.

Los pacientes se clasifican en tres grupos según la clínica: asintomáticos (80-88\%), síndrome de BP por oclusión intestinal $(0,3-5 \%)$ y síndrome de BP por intoxicación $(0,6-3 \%)^{1,2}$.

La radiología simple de abdomen es la técnica diagnóstica de elección, mostrando múltiples

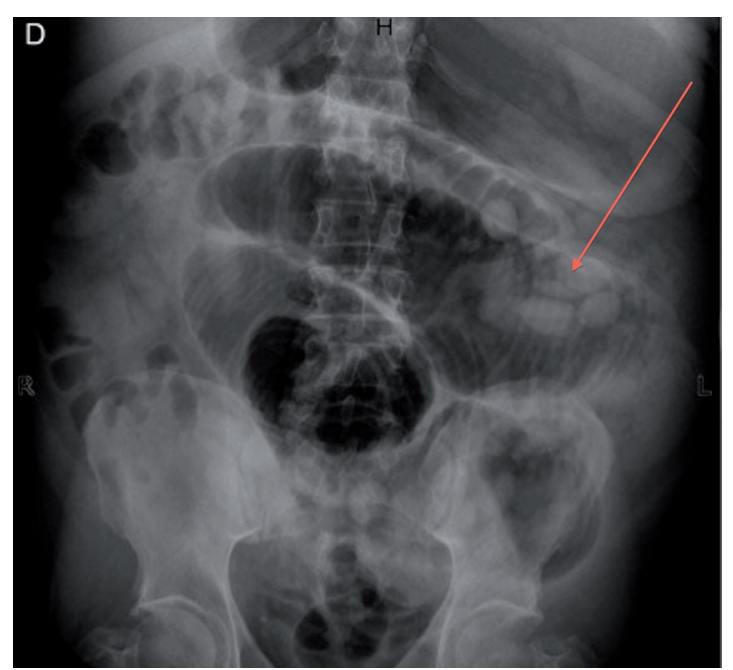

Figura 1. Radiología simple de abdomen, en donde se indica la presencia de múltiples imágenes correspondientes con los paquetes de hachís con la típica imagen del "signo del doble condón", producido por el aire que queda atrapado entre las diferentes capas del envoltorio.

*Recibido el 14 de marzo de 2013 y aceptado para publicación el 3 de abril de 2013.

Correspondencia: Dr. Antonio Palomeque J.

Plza. Ciudad de los Cármenes. Bloque 1. Portal 3. $6^{\circ} \mathrm{F}$.

Cód. Postal: 18013. Granada (Granada). España.

apalomeque2002@hotmail.com 


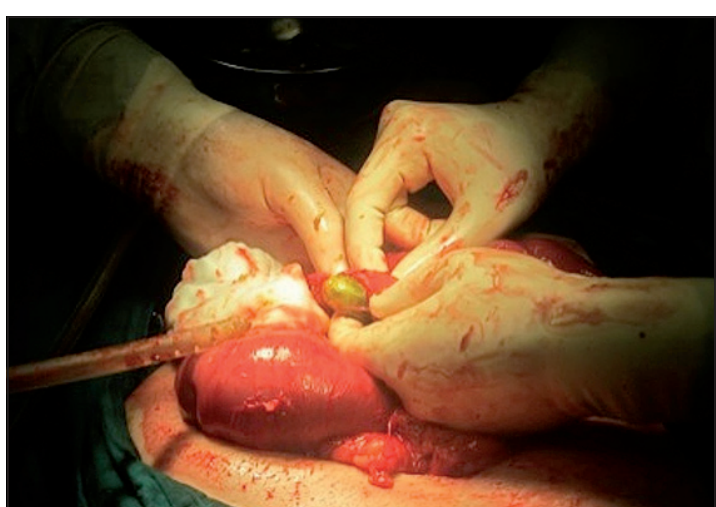

Figura 2. Imagen intraoperatoria, donde se observa la enterotomía por donde se realiza la extracción de los paquetes de hachís.

cuerpos radioopacos, bien definidos, densos, ovalados o cilíndricos y rodeados por imagen radiolúcida ("signo del doble condón"). La tomografía computarizada puede ser de utilidad, presentando mayor sensibilidad, siendo poco útiles la ecografía y la resonancia nuclear magnética ${ }^{2}$.

El tratamiento incluye actitudes conservadoras, con altas tasas de resolución, y procedimientos quirúrgicos urgentes ( $5 \%$ de los casos) en casos de intoxicación, hemorragia digestiva alta, perforación de víscera hueca, convulsiones y/o hipertensión arterial rebelde a tratamiento médico y oclusión intestinal resistente al tratamiento conservador ${ }^{3}$.

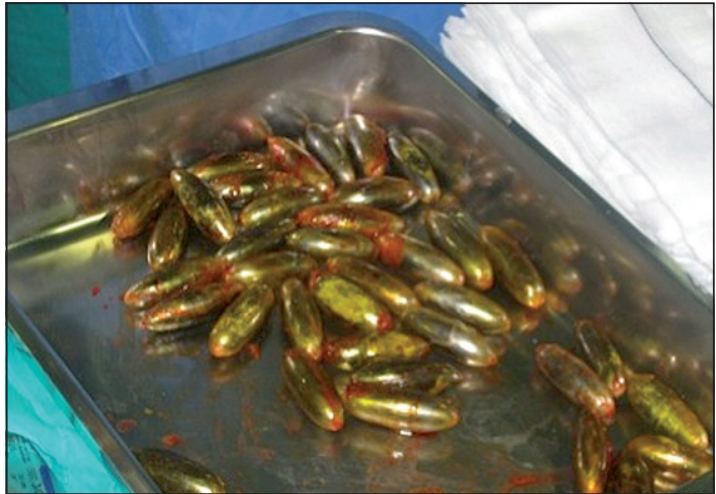

Figura 3. Imagen de los múltiples paquetes de hachís extraídos.

\section{Referencias}

1. Pidoto RR, Agliata AM, Bertolini R, Mainini A, Rossi G, Giani G. A new method of packaging cocaine for international traffic and implications for the management of cocaine body packers. J Emerg Med. 2002;23:14953.

2. Kulkarni VM, Gandhi JA, Gupta RA, Deokar RB, Karnik ND, Nadkar MY. Body packer syndrome. J Postgrad Med. 2012;58:225-6.

3. Megarbane B, Ekherian JM, Couchard AC, GoldgranToledano D, Baud F. Surgery to save body-packers. Ann Fr Anesth Reanim. 2004;23:495-8. 